\title{
Organising the 'industrialisation of instruction': Pedagogical discourses in the Swedish Primary Teacher Education programme
}

Lena Sjöberg

\begin{abstract}
This study examines the organisation of the Swedish Primary Teacher Education (PTE) programme by studying a local educational policy practice. The empirical material consists of policy documents and interviews with teacher educators at a large university. The study focuses on the pedagogical discourses in teacher education, by studying whether the examinations, courses, and education are based on insulation or integrating principles, that is, strong or weak classification. The results of the study show that both the national policy text and the local organisation are based on principles and rationalities of strong classification, where the local policy practice is both constructed through and affected by commodification and market rationalities.
\end{abstract}

Received 17 August 2019; revised version received 6 October 2019; accepted 28 October 2019. Corresponding author: Lena Sjöberg, University West, Sweden (lena.sjoberg@hv.se).

\section{Introduction}

This article explores how national higher education policy is transformed into educational practice and what material conditions influence implementation and praxis in higher education. The study is based on the Teacher Education programme, which is the largest of all Swedish university professional programmes. Furthermore, Teacher Education is the higher education programme that is most regulated and evaluated by the Swedish government. Strict regulation of teacher education (TE) is, however, not unique to Sweden; similar discursive governing mechanisms operate in other parts of the world as well. Another worldwide governing discourse is the focus on how teacher education is responsible for training highly qualified teachers as well as teacher education's significance in terms of progress of the educational system in general. This trend 
is rooted in 'think tanks' as well as international organisations such as the Organisation for Economic Co-operation and Development (OECD) and the World Bank (Ball, 2012; Barnes \& Cross, 2018; Darling Hammond \& Bransford, 2005; European Commission, 2015; Grek, 2009; McKinsey \& Co., 2007; OECD, 2005, 2015). For example, when the Swedish teacher education system was reformed in the beginning of the new millennium, the policy texts (SOU 2008:109) were based upon the so-called McKinsey Report, written by the global management consulting company McKinsey \& Company. This report pointed out the teachers as the single most important factor in determining the success and quality of the school system. The report claims that selecting the right individuals and training them to use effective teaching methods are the two most important factors in creating a competitive school system (McKinsey \& Co., 2007, p 13; SOU 2008:109, p 53).

The reformation of teacher education that, in 2011, resulted in new Swedish TE programmes shifted the discourses evident in previous teacher education reforms and was rationalised by referring to globally recognised, neoliberal discourses on education. It was also justified with reference to traditional Swedish teaching methods dating back to the 1950s. The new TE programmes are thus based upon both neoliberal and neoconservative rationalities (Sjöberg, 2010). The policy text, as well as the teaching practices that resulted from it, are both grounded in a more explicit focus on subject knowledge and subject didactics, ${ }^{1}$ concentrating on the specific subject in which the future teachers will be teaching. The reformation of the TE programmes thus represented a break with teacher training ideals that emphasised integration and cooperation, leading to programmes with a high degree of specialisation or strong classification (Beach \& Bagley 2012, 2013; Beach et al., 2014; Bernstein, 1996). One of the new programmes established by this reform was the Primary Teacher Education (PTE) programme, with its specialisations for preschool class teachers and teachers of grades 1-3 (K-3), grades 4-6, and teachers working in leisure-time centres. ${ }^{2}$

Previous research on pedagogical discourses in the new PTE programme has shown how the subject didactics focus dominates assessment of student teachers' knowledge and skills, that there are subcultures within the programmes due to its assessment practices (Player Koro \& Sjöberg, 2018), and that the current curriculum has a substantial influence on teacher education students' knowledge base (Sjöberg, 2018a). Finally, research demonstrates that there are

\footnotetext{
${ }^{1}$ Didactics is central in the context of the Swedish TE programme. The term comes from the Greek word for teaching (didaskein) and touches on both micro and macro aspects of teaching.

${ }^{2}$ The specialisation for leisure-time centre teachers is not included in this study due to it being different from the other primary teacher specialisations, historically speaking.
} 
significant differences between the various specialisations and subjects in terms of pedagogical discourses on assessment practice (Sjöberg, 2018b).

The present study is a continuation of a research project dealing with the new PTE programme and aims to examine the programme's pedagogical discourses in terms of the way that the programme is structured and the way its organisation affects the programme's content and the future teachers' knowledge base as well as their professional identity.

This study is structured according to the following research questions:

- How is the PTE programme organised, based upon principles of integration and insulation respectively (weak or strong classification), in terms of courses, and in assessments in the respective courses?

- What factors and rationalities affect and control the organisation of the programme and its praxis?

The study was carried out at a large Swedish university that educates primary teachers, and the empirical material consists of programme syllabi, course policy texts (course syllabi, study guides, and assessment tasks), and interviews with seven teacher educators.

\section{Theoretical framework}

This study is mainly grounded in Ball's and Bernstein's sociological theories of education policy and practice. It is also based on Ball's way of defining policy as both text and discourse (Ball, 2006). Furthermore, Braun et al. (2011) point out that institutional logics, contexts, and materialities are part of policy discourses (cf. Cochran Smith et al., 2018). This approach to policy implies that university lecturers, in this case teacher educators, and others involved in policy practices, participate in creating policy and can therefore be seen as both policy actors and policy subjects.

In addition to Ball's theoretical toolbox, Bernstein's theories and ideas are used to analyse the way educational policy is transformed into pedagogical practice (the pedagogic device) through pedagogic discourse (Bernstein, 1996). Bernstein defines pedagogic discourse as 'a principle for appropriating other discourses and bringing them into special relation with each other for the purposes of their selective transmission and acquisition' (Bernstein, 1990, p 181). Hence, pedagogic discourse not only relates to content but also to the way education and instruction are transformed, organised, and practised. Pedagogic discourse consists of both 'what' and 'how' aspects, through an instructional and a 
regulative discourse. The instructional discourse relates to the 'what-aspect' of education - that is, what content is to be taught and learned. The instructional discourse is embedded in the regulative discourse, which affects the 'how' of education. The regulative discourse works both at a general level and through concrete phenomena and situations. According to the current study, the regulative discourse influences the PTE programme through both overarching global and historical discourses and traditions and the local organisation of the programme.

This study places particular focus on classification as a part of the pedagogic device and the pedagogic discourse. An important basis for the concept of classification is, according to Bernstein, that power is constituted in the relationships between various entities, such as principles and practices of insulation and integration. Strong classification involves more distance between various entities (insulation), while weak classification involves less distance or even the hybridisation of various entities (integration). Classifications form symbolic relationships between and within discursive categories of the educational system - in this case, in the PTE programme. These symbolic relationships create, legitimise, and reproduce symbolic boundaries and 'messages of power' (Bernstein, 1996, p. 6) between, for example, various groups of individuals and categories of teaching and subjects. Bernstein asserts that it is in this way that power relations are created, social order is maintained, and pedagogic identities are shaped. Hence, important questions are: 'In whose interests is the apartness of things?'; 'In whose interests is the putting together of things?' These questions immediately raise the issue of the relationship of power relations to boundaries: 'Whose power is maintained and relayed by whose boundaries?' (Bernstein, 1996, p. 127)

With reference to the theoretical concepts mentioned above, the empirical material will also be analysed using the concept of commodification (Agnafors, 2018) and institutional logics (Freidson, 2001). These concepts are used to understand and draw attention to the organisational aspects of the pedagogic discourse in the PTE programme. Commodification deals with the process that constructs education as a product with commercial value (Agnafors, 2018; Werler, 2015). Freidson's (2001) three institutional logics - the bureaucratic, the professional, and market logic_ — can also explain how the pedagogic discourses are articulated in the programme. 


\section{Previous research}

In recent years, there has been considerable interest in studies concerning teacher education, and this interest has been focused on some particular areas. A large number of studies, both those done in the Nordic countries and internationally, deal with changing global discourses concerning education policy and how these discourses are disseminated. This research examines how these discourses depict the TE programme as a system in crisis, rendering it and other programmes around the world ever more standardised (Cochran Smith et al., 2013; Ensor, 2004; Maguire, 2014; Nordin, 2012; Sarakinioti \& Tstatsaroni, 2015). These studies show how international political actors and 'think tanks' operate as powerful policymakers and what effects these discourses have on national policy and local educational practice. Furthermore, the studies show how market logics - and to a certain extent, bureaucratic ones - have conquered the domains of higher education, where professional logics receive ever less attention, resulting in an objectification and commodification of education, educators, and students, including teacher educators and student teachers (Agnafors, 2018; Freidson, 2001 Page, 2019; Werler, 2015). With reference to discourses on the great importance school teachers have for the results of the educational system, quite a few international studies have examined how teachers' professionalism, 'teacher quality', and 'teacher knowledge' are constructed in and outside of teacher education programmes (Ben-Peretz, 2011; Berkovich \& Benoliel, 2018; Cochran-Smith et al., 2018; Hardy et al., 2018; Mockler, 2018; Nordin \& Wahlström, 2019).

With regard to global discourses on education, the most recent reorganisation of Swedish teacher education (SOU 2008:109) has been studied from the perspective of historical change or as a policy trajectory (Alvunger \& Wahlström, 2018; Beach \& Bagley, 2012, 2013; Beach et al., 2014; Nilsson Lindström \& Beach, 2015; Player Koro \& Sjöberg, 2018; Sjöberg, 2010; 2018a; 2018b; Wermke \& Höstfält, 2014). Among other things, these studies show that the TE programmes of 2011 are constructed upon neoliberal and neoconservative rationalities, breaking with a long tradition of continuity in educational logic. The studies also show that concerns expressed in the policy text regarding the subordination of didactic content in the TE programmes were unwarranted, since the didactic content is clearly dominant, at least in the assessment tasks. Studies also show how various sub-discourses have been created throughout different parts of the PTE programme, among the various teaching specialisations and in the different subjects (Player Koro \& Sjöberg, 2018; Sjöberg, 2018b). 
Other studies of the Swedish or Nordic context deal with specific content in teacher education and there has been particular interest in areas like placement (in Sweden this is called VFU) (Hegender, 2010; Jedemark, 2019; Karlsson Lohmander, 2015; Leeferink et al., 2018), degree project (Erixon Arreman \& Erixon, 2015; Gustavsson \& Eriksson, 2015), and the relationships between theory and practice (Saetra, 2018; Wågsås Afdal \& Spernes, 2018). In several studies, Wågsås Afdal has also compared the Finnish TE programme, which has a clear research approach, to the more profession-oriented Norwegian programme to see what consequences these different approaches and organisational perspectives have for the content of teacher education and for the future teachers' knowledge base and professional identity (Wågsås Afdal, 2012, 2017; Wågsås Afdal \& Nerland, 2014).

There are relatively few studies that focus on teacher educators' perspectives and/or the organisation of teacher education. Teacher educators' professionalism and professional identity have been studied by Beach and Angervall (2018), Dodillet and Lundin (2018), Jonker et al. (2018), and Vanassche and Keltermans (2014), among others. These studies show that a teacher educator's work and professional identity have changed in terms of new educational rationalities and the use of new technologies in higher education. One study by Zimmerman Nilsson (2017) also shows how teacher educators use rhetorical strategies to position themselves in relation to the programme's various goals and content - as practice-oriented, relations-oriented, or reflection/critical thinking-oriented teacher educators.

This study's contribution to existing research is its focus on the local organisation's significance for the programme's pedagogic discourses and, in the long run, for the knowledge base, the epistemological approach, and the professional identity that university students and, in this case, teacher education students, carry with them throughout the programme and into their future professions.

\section{The Swedish PTE programme and description of the studied university}

The Swedish PTE Programme is one of four TE programmes. ${ }^{3}$ The two PTE specialisations that focus on the primary grades are four-year programmes (240 credits), with the final year at the advanced level. The programme's content is

\footnotetext{
${ }^{3}$ The other teacher education programmes are the Preschool Teacher programme, the Vocational Teacher Education programme, and the Secondary and Upper Secondary School Teacher programme.
} 
regulated by a number of learning outcomes in the System of Qualification, ${ }^{4}$ but also by the subjects that the programme comprises as well as the subject scope (Higher Education Ordinance, SFS 1993:100). The subjects that are included in the programme are the educational science core (UVK), placement (VFU), and the subjects Swedish, English, mathematics, the natural sciences, and the social sciences. Students specialising in grades 4-6 can also choose to study a practical/aesthetic subject instead of the natural or social sciences. All students must also complete one or two degree projects. Every university has responsibility for constructing and organising the programme according to the above framework.

The present study has been carried out at a university with a long tradition of educating teachers. The Education Faculty is responsible for the PTE programme. The operative responsibility for courses is, however, spread out across the entire university with the idea that teacher education is everyone's responsibility and concern. ${ }^{5}$ The Education Faculty consists of several departments that are located in adjacent buildings. The other departments involved in teacher education belong to different faculties at the university.

Before the new TE programmes were introduced in 2011, the programmes were regulated by a teacher education board called LUN, which was in the form of a faculty board (without responsibility for employees). It was LUN that decided the economic, organisational, and content-related framework for the programme. Since 2011, re-organisation has taken place and today the PTE programme is regulated by a centrally situated board with overall responsibility for maintaining competency and organising coordination, strategic development, and quality assurance.

For each programme, there is also a programme board that has responsibility for the quality of course and programme syllabi as well as for the organisation of the programme. The programme board thus decides which department will be responsible for a course, which departments will be involved, and how educators' time will be distributed between the departments. A programme coordinator is responsible for programme content. Employees who work with the various TE programmes are, however, employed by their respective departments, under the administrative supervision of a head of department, with a director of studies doing the operational planning with regard to employees of the department.

\footnotetext{
${ }^{4}$ The current specialisations on the PTE programme have 27-28 learning outcomes.

${ }^{5}$ This reasoning was clearly articulated by the investigation done in conjunction with the previous Teacher Education programme (SOU 1999:63) and is also formulated in the internal documents of the university.
} 


\section{Data collection and analysis}

The empirical material consists of both text and interview data. The texts are policy texts for courses (course syllabi, study guides, and assessment tasks) in the PTE programmes K-3 and 4-6, as well as the programme syllabus. ${ }^{6}$ The text material is taken from 44 courses and 283 assessment tasks. The collection of the policy texts was done during the autumn of 2014 and spring of 2015, that is, during the academic year in which the students who had begun their studies in 2011 were doing their last year on the programme, making all course documents accessible.

\begin{tabular}{|c|c|c|}
\hline & Courses & $\begin{array}{l}\text { Examination } \\
\text { tasks }\end{array}$ \\
\hline Primary teacher education for grades K-3 & 22 & 136 \\
\hline Primary teacher education for grades $4-6$ & 22 & 147 \\
\hline Total & 44 & 283 \\
\hline
\end{tabular}

Table 1: The number of courses and assessment tasks studied.

During the spring of 2018, interviews were also conducted with seven teacher educators from the same university. An invitation to participate in the interview study was sent to all of the teacher educators who were course coordinators for a course that was part of the programme during 2018. Seven of the educators offered to participate in the study. The educators came from different departments and faculties at the university. They are in charge of courses from both specialisations (K-3 and 4-6), and every subject included in the study. To protect the anonymity of the informants, the academic degree, gender, and subject specialisation of interviewees are not revealed. In the results section, they are represented by the letters A-G. Six of the interviews were conducted at the university where the study was carried out, and one interview was conducted via video link. The interviews were semi-structured and included topics such as choice of content and assessment format in relation to their subject and courses, as well as how the programme was constructed when it was implemented and what now influences and regulates content and praxis of the programme. Each interview lasted between 45-60 minutes.

The analyses of text and interview data were carried out with the help of the qualitative data analysis software NVivo. A deductive approach was used to

\footnotetext{
${ }^{6}$ For the specialisation in grades 4-6, the students can choose to take 30 credits of social sciences, natural sciences, or one or more practical/aesthetic subjects. Since it was impossible to access material from several of the practical/aesthetic courses, those are not part of the study.
} 
analyse the textual data, primarily using Bernstein's (1996) theoretical concept of classification. Each course and each assessment task was examined to see whether they are formulated based on principles of insulation or integration, that is, whether they contain unconnected components or if the course and/or assessment task are based on a principle of integration. The course material was coded based upon two variables: strong or weak classification. A course that was coded as having strong classification is clearly split up into different thematic sections that are not explicitly connected through lectures/seminars or assessment tasks. A course that was coded as having weak classification contains integrated content. Likewise, all the assessment tasks were coded, but this time with three variables. A task coded as having strong classification deals with a limited aspect of a subject/course. A task with weak classification includes themes/content from various elements of the subject/course. An assessment task coded as having average-classification contains several aspects or a somewhat broader area, but lacks aspects that cut across subject boundaries. After the coding of all the courses and assessment tasks, a quantitative, descriptive analysis was carried out to reveal how the courses and assessment tasks are constituted in relation to classification (Bernstein, 1996).

The analyses of the interviews were also done using NVivo, but in this case the approach was based on inductive reasoning. The analyses were grounded in the topics used to structure the interviews. In the analysis phase, the inductive work involved finding common themes and patterns, as well as differences, based upon both the informants' perspectives and the theoretical framework of the study. Quite early on in the interview process, it became clear that organisational factors stood out as important for the construction of courses and content in the PTE programme, and through this, the construction of the pedagogic discourses in the programme.

\section{Results}

One of the goals of the new Swedish TE programmes was to more clearly focus on various forms of school education by concentrating teacher knowledge on the future pupils' ages and 'maturity' as well as on subjects, subject didactic knowledge, and skills (SOU 2008:109). The previously comprehensive TE programme has now become four distinct programmes, and the System of Qualifications in the Higher Education Ordinance (SFS 1993:100) constructs a difference between subjects by making explicit the scope of each subject. The overarching premise and principle of teacher education is then a strong classification. 


\section{Classification in courses}

By analysing the 44 courses that are offered in the current PTE programme, it can be seen that one third of the courses is structured around the principle of strong classification. The study guides show that content in these courses is organised into separate modules and consists of content that does not together form a coherent and integrated whole (Table 3). The percentage of courses characterised by strong classification is somewhat larger in the specialisation for grades 4-6 than it is in the K-3 specialisation ( $36 \%$ as opposed to $27 \%$ ).

\begin{tabular}{|l|ll|ll|ll|}
\hline & $\begin{array}{l}\text { K-3 } \\
\text { Number }\end{array}$ & $\%$ & $\begin{array}{l}\mathbf{4 - 6} \\
\text { Number }\end{array}$ & $\%$ & $\begin{array}{l}\text { Total } \\
\text { Number }\end{array}$ & \% \\
\cline { 2 - 6 } $\begin{array}{l}\text { Strong } \\
\text { classification }\end{array}$ & 6 & 27 & 8 & 36 & 14 & 32 \\
$\begin{array}{l}\text { Weak } \\
\text { classification }\end{array}$ & 16 & 73 & 14 & 64 & 30 & 68 \\
Total & $\mathbf{2 2}$ & & $\mathbf{2 2}$ & & $\mathbf{4 4}$ & \\
\hline
\end{tabular}

Table 2: Classification in courses, both specialisations.

The results also show that there is a difference between subjects in terms of how the courses are constructed; all the courses that are part of the mathematics, English, the natural sciences, and the social sciences subjects are based on a principle of strong classification. Courses in the educational science core, the degree project, and placement all have weak classification of content. Courses in Swedish are characterised by a combination of principles.

\begin{tabular}{|c|c|c|c|c|c|c|c|c|c|c|c|c|c|c|c|c|c|}
\hline \multirow{5}{*}{$\begin{array}{l}\text { Strong } \\
\text { classification } \\
\text { Weak } \\
\text { classification } \\
\text { Total }\end{array}$} & \multirow{2}{*}{\multicolumn{2}{|c|}{$\begin{array}{l}\text { Swedish } \\
\text { No } \% \\
\end{array}$}} & \multicolumn{2}{|c|}{ Mathematics } & \multicolumn{2}{|c|}{ English } & \multicolumn{2}{|c|}{$\begin{array}{c}\text { Social } \\
\text { sciences }\end{array}$} & \multicolumn{2}{|c|}{$\begin{array}{l}\text { Natural } \\
\text { sciences }\end{array}$} & \multicolumn{2}{|c|}{$\begin{array}{c}\text { Educational } \\
\text { science } \\
\text { core }\end{array}$} & \multicolumn{2}{|c|}{$\begin{array}{l}\text { Degree } \\
\text { project }\end{array}$} & \multicolumn{2}{|c|}{ Placement } & Total \\
\hline & & & No & $\%$ & No & $\%$ & No & $\%$ & No & $\%$ & No & $\%$ & No & $\%$ & No & $\%$ & No $\%$ \\
\hline & 3 & 60 & 4 & 100 & 3 & 100 & 2 & 100 & 2 & 100 & 0 & 0 & 0 & 0 & 0 & 0 & $14 \quad 32$ \\
\hline & 2 & 4 & 0 & 0 & 0 & 0 & 0 & 0 & 0 & 0 & 16 & 100 & 4 & 100 & 8 & 100 & 30 \\
\hline & 5 & & 4 & & 3 & & 2 & & 2 & & 16 & & 4 & & 8 & & 44 \\
\hline
\end{tabular}

Table 3: Classification in courses, all subjects. 


\section{Classification in assessment tasks}

Analyses of assessment tasks show that those characterised by a weak classification dominate (54\%), and this applies to both grade specialisations. In the specialisation for grades 4-6, there is a somewhat higher number of tasks with strong classification ( $8 \%$ as opposed to $5 \%$ ), but in general, tasks that deal with only a very limited part of the subject are uncommon.

\begin{tabular}{|l|ll|ll|ll|}
\hline & \multicolumn{2}{|c|}{ K-3 } & \multicolumn{2}{c|}{ 4-6 } & \multicolumn{2}{c|}{ Total } \\
\cline { 2 - 7 } $\begin{array}{l}\text { Strong } \\
\text { classification }\end{array}$ & 7 & 5 & 12 & 8 & 19 & 7 \\
$\begin{array}{l}\text { Average } \\
\text { classification }\end{array}$ & 57 & 42 & 55 & 37 & 112 & 39 \\
$\begin{array}{l}\text { Weak } \\
\text { classification }\end{array}$ & 72 & 53 & 80 & 54 & 152 & 54 \\
\cline { 2 - 7 } & 136 & 147 & & 283 & \\
\hline
\end{tabular}

Table 4: Classification in assessment tasks, both specialisations.

A comparison between the different subjects and research fields shows that there are differences in culture between subjects when it comes to the way assessment tasks are constructed. The few tasks that are characterised by strong classification can be found in three of the subjects: the natural sciences (38\% of the assessment tasks in this subject), English (17\%), and mathematics (13\%). With the exception of the degree project, the subjects in which classification is weakest and assessment tasks reflect an integrated approach are in placement $(100 \%)$ and the social sciences $(76 \%)$. Most subjects mix tasks characterised by a weak and an average classification.

\begin{tabular}{|c|c|c|c|c|c|c|c|c|c|c|c|c|c|c|c|c|c|c|}
\hline \multirow{3}{*}{$\begin{array}{l}\text { Strong } \\
\text { classification }\end{array}$} & \multicolumn{2}{|c|}{ Swedish } & \multicolumn{2}{|c|}{ Mathematics } & \multicolumn{2}{|c|}{ English } & \multicolumn{2}{|c|}{$\begin{array}{c}\text { Social } \\
\text { sciences }\end{array}$} & \multicolumn{2}{|c|}{$\begin{array}{l}\text { Natural } \\
\text { sciences }\end{array}$} & \multicolumn{2}{|c|}{$\begin{array}{l}\text { Educational } \\
\text { science } \\
\text { core }\end{array}$} & \multicolumn{2}{|c|}{$\begin{array}{l}\text { Degree } \\
\text { project }\end{array}$} & \multicolumn{2}{|c|}{ Placement } & \multicolumn{2}{|c|}{ Total } \\
\hline & & $\%$ & No & $\%$ & No & $\%$ & No & $\%$ & No & $\%$ & No & $\%$ & No & $\%$ & No & $\%$ & No & $\%$ \\
\hline & 1 & 3 & 2 & 13 & 4 & 17 & 0 & 0 & 8 & 38 & 4 & 4 & 0 & 0 & 0 & 0 & 19 & 7 \\
\hline $\begin{array}{l}\text { Average } \\
\text { classification }\end{array}$ & 17 & 42 & 4 & 27 & 12 & 50 & 10 & 24 & 6 & 29 & 63 & 70 & 0 & 0 & 0 & 0 & 112 & 39 \\
\hline $\begin{array}{l}\text { Weak } \\
\text { classification }\end{array}$ & 22 & 55 & 9 & 60 & 8 & 33 & 32 & 76 & 7 & 33 & 23 & 26 & 13 & 100 & 38 & 100 & 152 & 54 \\
\hline Total & 40 & & 15 & & 24 & & 42 & & 21 & & 90 & & 13 & & 38 & & 283 & \\
\hline
\end{tabular}

Table 5: Classification in assessment tasks, all subjects. 
Factors that affect organisation and content: the teacher educators' voices

What emerges in the analysis of policy documents reflects the descriptions that the seven teacher educators provide in the interviews. They reveal an organisation that is influenced by 1) discourses within the subject and how that subject is constructed in schools and in curricula, but mainly they say that the content of the programme is significantly influenced by factors such as 2) organisation and 3) economic rationalities. Together these factors create the possibility of a strong classification in the organisation and content of the programme (the pedagogic discourse).

The first factor that is raised and affects organisation and content of the PTE programme courses deals with the subject's need to define the subject area's 'core', both inside the academic institution and out in the schools. This is where the subject of natural sciences, for example, is described as having gone from being characterised by a weak classification in both specialisations (in grades K-3 and 4-6) to being more insulated and based on a stronger classification principle:

D - The thought was that both K-3 and 4-6 should have it that way so that they would understand that all subjects are related to each other and that one can discuss certain things as cutting across subject boundaries between the various subjects, there we have deviated from the path a bit, so I don't really think we are there today.

I - Why do you think there's been a deviation? And in what way has this happened?

D - I think that it's because there is a, a desire to highlight the subjects each one by itself and also a need among the students to understand one thing at a time. So that it's like moving toward, we have more distinct physics, chemistry, and biology specialisations in the courses and surely also because of us who work with this and because of the way the school looks upon it.

I - You mean the primary school?

$\mathrm{D}-$ Yes, out in the schools and the curricula and syllabi that are there now, even though it is natural sciences for K-3 there is a more distinct specialisation of the subjects. (Informant D)

The other regulating factor is that of the programme's organisation. The programme's basic construction within the educational science core (UVK) and for placement (VFU) is made up of 7.5-credit modules, similar to the proposal that was made in the national policy text (SOU 2008:109). Since the policy text and the System of Qualifications (SFS 1993:100) describes a common educational science core, regardless of which teacher education programme, initially it was decided that these courses should be identical for the various programmes offered at the university. This initial decision has meant that it is difficult to make changes to or between courses: 
What regulates us is that they decided on these modules and this was decided centrally by the teacher education board. Modules worth 7.5 credits. The core courses [UVK] were supposed to be worth 7.5 credits and placement courses were to be 7.5 credits and there were to be four of them. All such framework and structures, but content-wise there was an opportunity to have some influence, that was the way I felt. /.../ For courses in subjects it's not so dicey, but the core of educational science is 7.5 credits and many of them are common for all teacher education programmes and then it's not so easy to move things around in them and it is I think one of the biggest regulating factors that we have. (Informant D)

The third, but most salient factor raised by interviewees relates to the assumption that the TE programmes are supposed to be the entire university's concern. The result of that approach is that an economic system for buying and selling courses and lecturers has been created, in which courses are said to be 'owned' by different departments. According to the informants, the portion of a course that a specific department contributes to and is responsible for is a fait accompli. According to the informants, this is not something that is decided on the basis of content or competence; instead, there is a given distribution between faculties and departments. Furthermore, there are co-opted lecturers who not only teach in the PTE programme but are also employed by a primary school. The system for buying and selling courses and lecturers generates more administrative tasks and, in some cases, a collision in content rationality regarding what a future teacher needs in terms of training:

E - No, we collaborate with [name of department]. So they are involved in about $20 \%$ of the courses.

I - What do they do?

E - Yes, what do they do, that's a good question. I, we can say that their purpose is to see to it that the students' own [subject] knowledge is deepened. They are not specialists in didactics /.../ And then there is also a conflict between us and [name of department] how well this, well it's really closely tied to specific people, which lecturer will come. Some are interested in teaching and learning and in the students and then it works really well. But there are in fact lecturers from departments devoted to a specific subject who are only interested in their subject.

I - But is it determined from the start that they should have $20 \%$ ?

$\mathrm{E}-$ Yes, or yes this has been negotiated, there are, so we used to have LUN [i.e., the teacher education board]. Do you know what that is? And then it was that board who negotiated and there are agreements between the heads of department and the departments as to how many should be involved in one another's courses and which faculties should collaborate and how much. Then it's not carved in stone, one can of course have negotiations about this. (Informant E) 
The size of the programme, together with the way it is structured and organised, has led to a number of difficulties in collaboration, which partly have to do with geography, but also partly with access to things like cardkeys that are needed to meet with colleagues in person:

I - Do you collaborate between Swedish and English, I mean grammar is part of both [subjects]?

F - It is weak, we have wanted to arrange a collaboration and we feel that we are in this building, all the others are in [name of building] so we don't have any meetings other than when there are meetings for course coordinators. /.../ That would be, that is what we want, we come from schools so we are used to working together, now we collaborate within the course but we have, we feel, we would like to collaborate more.

I - And so it's sort of the geography, the street that makes it like this?

F - The street and different buildings, which make it so that we don't meet. We don't meet for coffee or we can't chat and discover how nice it would be. (Informant F)

It's not any great distance, it's like a few hundred metres up [...] but we don't even have cardkeys, we can't get into the building /.../ It is symbolic so I sort of flirted with a caretaker and I have a key now. I am there every term, should I like need to return the key then? (Informant A)

The teacher educators relate that the overall organisation affects the continuity of the programme and courses. First, it is seldom that the same people teach in the same course for any length of time; it is difficult to arrange staff meetings among teachers, and it is seldom that lecturers in different courses meet with one another to facilitate programme cohesion:

B - So there are fifteen lecturers, something like that and that is for me the greatest challenge. I have been a course coordinator previously for several courses, but it's been me and maybe three more at the most and it's a whole different kit and caboodle to both have so many lecturers and from so many different places /.../ And so they choose the people they want to have from their department who they want so we have like a list of these people who come from this department on this course and add to that a director of studies. Then I think that in principle we can say no thanks, we don't want that person.

I - But how many of these fifteen, how many are from this department and how many come from other departments and which ones?

B - There might be five from here, two come from [name of dept] and the rest from [name of faculty] and two or three [name of department], but then there are from $/ . . . /$ I will never learn the various acronyms in [name of faculty].

I - What logistics. 
B - Yes, but it is really like this and it is mainly this that one has noticed a lot, admin-related. Then it can absolutely be the case that, one can feel that it is terribly time-consuming to sit and combine email [addresses] to all of these lecturers and reminders if you don't get any answer. /.../ And I think that if you have a small course in a small department where you can go and knock [on a door] instead of sending group email and so on so you are several colleagues and I wonder about this and so it's clear that it becomes two very different situations, but I find that it is hard to get away from the fact that it is you have to deal with it differently and I think that having direct meetings is very important. (Informant B)

The educators also describe a sense of hierarchy that affects the way the PTE programme is organised and, in the long run, its content. This feeling can be related to the fact that, for courses in the educational science core (UVK), there is a difficulty with retaining lecturers with subject or subject didactic expertise:

A - But that's the way they plan our posts quite simply. The director of studies sits there and is supposed to put together Lisa's and Johan's posts and so they ask Lisa would you rather be in [subject A] or in this core course or the course coordinator for [subject B] didactics says, 'Damn right', Lisa should naturally $/ . . . /$ be in [subject A] since she has a PhD in [subject A] didactics. So it becomes a little like the trash heap.

I - But you feel that the educational science core becomes the trash heap?

A - Yes, that's the way it is. In the placement course (VFU) too, I believe, so I would guess so. (Informant A)

The teacher educators also highlight that some lecturers from the departments for specific subjects, outside the education faculty, sometimes are not interested in teaching on the PTE programme, which affects the continuity of the programme:

She was with us for many years. Now she is only on the K-3 [course] since she doesn't have time anymore and then afterwards there have been many different people. In our second course for 4-6 [teachers], the final 15 credits, it has unfortunately turned out so that every other term one person comes and every other term another person comes. But they are the same then but they switch terms and that means that the one works really well and the other not at all. So it's really difficult to, yes, it is a little bumpy. /.../ Sometimes someone comes who truly thinks it is interesting and then it's very good, but for many we have probably realised that it was that person's bad luck to get that [teaching assignment on the PTE programme] this year. (Informant E)

At the same time, many of the informants express the feeling that it would be best if there were a group of lecturers in the department, or faculty, who had sole responsibility for the course, including the teaching: 
I - But would that work if you, all twenty of you [lecturers in the subject at the department] had the courses [in the subject]?

E - We feel that it would work, then I will say that there are certain individuals who are very good who contribute a great deal but sometimes it gets messier when they [the teacher education students] are standing here crying and we spend all our time on [name of subject content] because it is so difficult and we don't have time to read what you are teaching because that is what feels important. (Informant E)

Despite the strength of organisational and economic factors, the teacher educators both want to and try to improve the programme where there is free space to do so. This is done primarily in the various subjects or between the specialisations within the educational science core:

I - If you yourself could decide, what would you like add or change?

$\mathrm{G}-$ Yes, I think that it relates a bit to what we mentioned before, how we work together. I can't say what is lacking in various courses and so forth really but I think that we should work together more so that the progression is more obvious and that we make it more obvious what the students get when it comes to certain things so that it is built up, that the courses are not so isolated. For example, there's the issue of guardianship that is there in the corner, and so a little bit in the corner there, but how do we actually work with this throughout the entire programme? Then there should be a more obvious progression and collaboration between courses, that's what I think. (Informant G)

\section{Discussion}

The compiled results of this study show that most of the assessment tasks that are constructed in the PTE programme have a weak or average classification, which means that they are constructed based on the holistic integrated principle of content coherence. Individual subjects, however, demonstrate a stronger classification principle. This applies to mathematics, the natural sciences, and English, which has also been shown in a previous study to be constructed partially on the basis of another pedagogic discourse, with a more distinct emphasis on individually written assessment structures with a greater degree of an atomised knowledge structure, compared to other subjects and research fields in the PTE programme. In a review of the way courses are constructed, results show that one third of all the courses in the programme are based on a strong classification, that the course content is structured around distinctly different parts. It is also mainly in the teaching subjects of courses that the principles of insulation exist. 
The large proportion of assessment tasks characterised by weak classification indicates that the epistemological approach embraced by most teacher educators is holistic. Educators try to construct tasks that are characterised by principles of coherence and comprehensive content coverage. The organisation of courses - in which many actors are involved - and their geographical spread result in diverse and more tightly defined course content and assessment tasks.

The informants describe a PTE programme with content defined by its organisation - an organisation that is based upon the suggestions and rationalities expressed in the national policy text (SOU 2008:109): that its basic structure should be strongly classified. Another problematic rationality concerns the notion that that teacher education should be the entire university's concern. The result of these basic rationalities is that the PTE programme and its content have become both atomised and commodified. Furthermore, courses and lecturers are treated like products with particular values that can be traded between departments and faculties.

The transformation from policy text to policy practice, the pedagogic device (Bernstein, 1996), has, according to the informants, facilitated the emergence of a bureaucratic system where cooperation and collaboration are difficult to manage. Due to the way the programme is organised, it falls upon a course coordinator to deal with (mail) system logistics so that all the involved educators know what they are supposed to do and when. In the subjects, and in conjunction with the courses being offered, the educators try to meet to plan content and progression. Nevertheless, the informants say that there are very few physical areas where the teacher educators can create coherence and progression within the subjects and for the whole programme. The physical distance and physical artefacts, such as cardkeys, also affect opportunities to work together across subject, department, and faculty boundaries and in the long run they also affect the coherence of the PTE programme. Other aspects that are of influence are the feeling that there is a lack of continuity in the courses and the status hierarchy in place that determines both programme content and the status of the entire PTE programme. Many of the informants say that teaching in the PTE programme does not have high priority and sometimes is seen as a necessary evil. The teacher educators do their best to find areas for collaboration both for their own sake and to improve the programme, but also for the sake of the students who are specialising in education for different age groups so that their educational experience and approach will have more breadth.

Overall, the study shows that the most recent reform of teacher education is grounded in a neoliberal rationality (Beach \& Bagley, 2012, 2013; Sjöberg, 2010), in policy and practice. The organisation of the programme is characterised by a neoliberal rationality, in which the market and, to a certain extent, the logics of 
institutional bureaucracy, substantially affect the form and content of the programme. Professional logics are no longer voiced as they once were (Freidson, 2001. According to Bernstein's (1990) theories of pedagogic discourses, the instructional discourse - the content-is affected by the overall regulative discourse. In this way, not only the content of the programme, but also the students' knowledge base and professional identity are influenced by both policy text discourses as well as material and organisational aspects of policy practice (Braun et al., 2011) in teacher education as well as in other university programmes. The results of this study show that the way that education and teaching are constructed in terms of the organisation of the PTE programme is, to a great extent, based on a strongly classified rationality, from policy to practicea rationality that will in all likelihood be the one that shapes the future teachers' way of viewing the construction of education and teaching practices, and possibly also their own teaching practice and professional identity.

Finally, I cannot help being reminded of an expression that is somewhat scoffed at: 'the industrialisation of instruction', about the way education departments in Sweden have come to function like industries/factories that produce teachers. The expression is often interpreted as being grounded in the size of the national TE programme since, as stated, it is the largest professional programme in the country. But in light of these results, the factory or industry metaphor gains a new and problematic weight, emphasising a market rationality that treats content, courses, and educators like commodities that can be bought and sold. Considering a political discourse that defines a teacher as the single most important factor leading to individual and system-wide educational success, teacher education and its organisation need to be taken seriously. The entire university should be responsible for teacher quality, but the results of this study indicate that this responsibility is not currently allocated in an effective way. Responsibility does not end within the universities. This study, together with previous research on the new Swedish PTE programme (Alvunger \& Wahlström, 2018; Beach \& Bagley, 2012; 2013; Beach, Bagley, Eriksson et al., 2014; Nilsson Lindström \& Beach, 2015; Player Koro \& Sjöberg, 2018; Sjöberg, 2010, 2018a, 2018b; Wermke \& Höstfält, 2014), clearly show that the conditions under which teacher education operates - strict regulation, constant evaluation, and a lack of financing - must change. If not, the job of educating 'high-quality' educators will become an impossible task. 


\section{Author biography}

Lena Sjöberg is an Associate Professor at the Teacher Education Department at University West in Trollhättan, Sweden. Her research concerns policy and political aspects of educational issues. This article is part of a research project on the implementation of a new teacher education reform in Sweden.

\section{References}

Agnafors, M. (2018). Inledning. Om kommodifiering av akademin. Universitet AB. Om kommodifiering, marknad och ekonomi. Göteborg: Daidalos.

Alvunger, D., \& Wahlström, N. (2018). Research-based teacher education? Exploring the meaning potentials of Swedish teacher education. Teachers and teaching: Theory and practice, 24(4), 332-349.

Ball, S. J. (2006). Education policy and social class: The selected works of Stephen Ball. New York: Routledge.

Ball, S. J. (2012). Global Education Inc.: New policy networks and the neoliberal imaginary. New York: Routledge.

Barnes, M., \& Cross, R. (2018). 'Quality' at a cost: The politics of teacher education policy in Australia. Critical Studies in Education. doi:10.1080/17508487.2018.1558410

Beach, D., \& Bagley, C. (2012). The weakening role of education studies and the re-traditionalisation of Swedish teacher education. Oxford Review of Education, 38(3), 287-303.

Beach, D., \& Bagley, C. (2013). Changing professional discourses in teacher education policy back towards a training paradigm: A comparative study. European Journal of Teacher Education, 36(4), 379-392.

Beach, D., Bagley, C., Eriksson, A., \& Player Koro, C. (2014). Changing teacher education in Sweden: Using meta-ethnographic analysis to understand and describe policy making and educational changes. Teaching and Teacher Education, 44, 160-167.

Beach, D., \& Angervall, P. (2018). Akademins 'hemmafruar': Om kvinnliga lektorers arbete i högskolans service- och tjänstesektor. In Agnafors, M. (Ed.), Universitet AB. Om kommodifiering, marknad och ekonomi (pp 93116). Göteborg: Daidalos.

Ben-Peretz, M. (2011). Teacher knowledge: What is it? How do we uncover it? What are its implications for schooling? Teaching and Teacher Education, 27, 3-9. 
Berkovich, I., \& Benoliel, P. (2018). Marketing teacher quality: Critical discourse analysis of OECD documents on effective teaching and TALIS. Critical Studies in Education. doi: 10.1080/17508487/2018.1521338

Bernstein, B. (1990). Class, codes and control: The structuring of pedagogic discourse (Vol 4). London: Routledge.

Bernstein, B. (1996). Pedagogy, symbolic control and identity: Theory, research, critique. London: Taylor and Francis.

Braun, A., Ball, S. J., Maguire, M., \& Hoskins, K. (2011). Taking context seriously: Towards explaining policy enactment in the secondary school. Discourse: Studies in the Cultural Politics of Education, 32(4), 585-596.

Cochran Smith, M., Piazza, P., \& Power, C. (2013). The politics of accountability: Assessing teacher education in the United States. The Educational Forum, 77(1), 6-27.

Cochran Smith, M., Stringer Keefe, E., \& Cummings Carney, M. (2018). Teacher educators as reformers: Competing agendas. European Journal of Teacher Education, 41(5), 572-590.

Darling Hammond, L., \& Bransford, J (Eds.). (2005). Preparing teachers for a changing world: What teachers should learn and be able to do. San Francisco, CA: Jossey-Bass.

Dodillet, S., \& Lundin, S. (2018). Constructing professionalism in teacher education: Analytical tools from a comparative study. Education Inquiry. doi:10.1080/20004508.2018.1529527

Ensor, P. (2004). Modalities of teacher education discourse and the education of effective practitioners. Pedagogy, Culture and Society, 12(2), 217-232.

Erixon Arreman, I., \& Erixon, P-O. (2015). The degree project in Swedish Early Childhood Education and Care - What is at stake? Education Inquiry, 6(3), 309-332.

European Commission. (2015). Shaping career-long perspectives on teaching: A guide on policies to improve initial teacher education. ET 2020. Retrieved 2019-10-30 from https://ec.europa.eu/epale/sv/node/16592

Freidson, E. (2001). Professionalism: The third logic. Cambridge: Polity Press.

Grek, S. (2009). Governing by numbers: The PISA 'effect' in Europe. Journal of Education Policy, 24(1), 23-27.

Gustavsson, S., \& Eriksson, A. (2015). Blivande lärares frågor vid handledning Gör jag en kvalitativ studie med kvantitativa inslag? Pedagogisk forskning $i$ Sverige, 1-2, 79-99.

Hardy, I, Rönnerman, K., \& Beach, D. (2018). Teachers' work in complex times: The 'fast policy' of Swedish school reform. Oxford Review of Education. doi:10.1080/03054985.2018.1546684 
Hegender, H. (2010). Mellan akademi och profession: Hur lärarkunskap formuleras och bedöms $i$ verksamhetsförlagd lärarutbildning. Linköping: Linköpings universitet.

Jedemark, M. (2019). A scientific approach in the assessment of the school-based part of the teacher education programme in Sweden. Journal of Curriculum Studies. doi:10.1080/00220272.2019.1567820

Jonker, H., Marz, V., \& Voogt, J. (2018). Teacher educators' professional identity under construction: The transition from teaching face-to-face to a blended curriculum. Teaching and Teacher Education, 71(1), 120-133.

Karlsson Lohmander, M. (2015). Bridging 'the gap' - Linking workplace-based and university-based learning in preschool teacher education in Sweden. Early Years, 35(2), 168-183.

Leeferink, H., Koopman, M., Beijaard, D., \& Schellings, G. L. M. (2018). Overarching professional identity themes in student teacher workplace learning. Teachers and Teaching, 25(1), 69-89.

Maguire, M. (2014). Reforming teacher education in England: 'An economy of discourse of truth'. Journal of Education Policy, 29(6), 774-784.

McKinsey \& Company. (2007). How the world's best-performing school systems come out on top. Stockholm: McKinsey \& Company Inc.

Mockler, N. (2018). Discourse of teacher quality in the Australian print media 2014-2017: A corpus-assisted analysis. Discourse: Studies in the Cultural Politics of Education. doi:10.1080/01596306.2018.1553849

Nilsson Lindström, M., \& Beach, D. (2015). Changes in teacher education in Sweden in the neo-liberal education age: Toward an occupation in itself or a profession for itself? Education Inquiry, 6(3), 241-158.

Nordin, A. (2012). Kunskapens politik - en studie av kunskapsdiskurser i svensk och europeisk utbildningspolicy. Växjö: Linnéuniversitetet.

Nordin, A., \& Wahlström, N. (2019). Transnational policy discourses on 'teacher quality': An educational connoisseurship and criticism approach. Policy Futures in Education, 17(3), 438-454.

OECD. (2005). Teachers' matters. Attracting, developing, and retaining effective teachers. Paris: OECD Publishing.

OECD. (2015). Improving schools in Sweden: An OECD-perspective. Paris: OECD.

Page, D. (2019). The academic as consumed and consumer. Journal of Education Policy. doi:10.1080/12680939.2019.1598585.

Player Koro, C., \& Sjöberg. L. (2018). Becoming a primary education teacher Pedagogic discourses in the teacher education programme's examination practice. Nordic Journal of Studies in Educational Policy, 4(2), 78-91. 
Saetra, E. (2018). Om forholdet mellom teori og praksis i laererutdanning. Norsk pedagogisk tidskrift, 102(4), 340-350.

Sarakonioti, A., \& Tstatsaroni, A. (2015). European education policy initiatives and teacher education curriculum reforms in Greece. Education Inquiry, 6(3), 259-288.

Sjöberg, L. (2010).'Same same, but different': En genealogisk studie av den 'goda' läraren, den 'goda' eleven och den 'goda' skolan i svenska lärarutbildningsreformer 1940-2008. EDUCARE, (1), 73-99.

Sjöberg, L. (2018a). The shaping of pre-service teachers' professional knowledge base through assessments. European Journal of Teacher Education. doi:10.1080/02619768.2018.1529751

Sjöberg, L. (2018b). The Swedish primary teacher education programme: At the crossroads between two education programme traditions. Education Inquiry. doi:10.1080/20004508.2018.1492845

SOU 1999:63. Att lära och leda. En lärarutbildning för samverkan och utveckling. Stockholm: Fritzes.

SOU 2008:109. En hållbar lärarutbildning. Betänkande av Utredningen om en ny lärarutbildning (HUT 07). Stockholm: Fritzes.

Vanassche, E., \& Keltermans, G. (2014). Teacher educators' professionalism in practice: Positioning theory and personal interpretative framework. Teaching and Teacher Education, 44, 117-127.

Werler, T. (2015). Commodification of teacher professionalism. Policy Futures in Education, 14(11), 60-76.

Wermke, W., \& Höstfält, G. (2014). Silent and explicit borrowing of international policy discourses: The case of the Swedish teacher education reforms of 2001 and 2011. Education Inquiry, 5(4), 445-460.

Wågsås Afdal, H. (2012). Knowledge in teacher education curricula: Examining differences between a research-based program and a general professional program. Nordic Studies in Education, 32(3-4), 245-261.

Wågsås Afdal, H. (2017). 'Research based' and 'profession-oriented' as prominent knowledge discourses in curriculum restructuring of professional programs. Higher Education: The International Journal of Higher Education Research, 74(3), 401-418.

Wågsås Afdal, H., \& Nerland, M. (2014). Does teacher education matter? An analysis of relations to knowledge among Norwegian and Finnish novice teachers. Scandinavian Journal of Educational Research, 58(3), 281-299.

Wågsås, Afdal, H., \& Spernes, K. (2018). Designing and redesigning researchbased teacher education. Teaching and Teacher Education, 74, 215-228. 
Journal of Praxis in Higher Education, Vol. 1 No. 1 (2019)

Zimmerman Nilsson, M-H. (2017). Practical and theoretical knowledge in contrast: Teacher educators' discursive positions. Australian Journal of Teacher Education, 42(8), 29-42. 